\title{
European Union Considers Banning Animal Testing for Cosmetics
}

On 7 November 2002, representatives of the European Parliament and the Council, which is comprised of representatives from the European Union's (EU's) 15 member governments, agreed to modify Directive 76/768/EEC (ref. 1) by introducing a ban on animal testing for cosmetic products ${ }^{2}$. This ban still needs to be approved by the full European Parliament and member nations.

The purpose of this new directive is to protect and improve the welfare of animals used for experimental purposes by promoting the development and use of scientifically valid methods of alternative testing. The directive has four main objectives:

- " $[\mathrm{T}] \mathrm{o}$ prohibit in the Community the testing of cosmetic products on animals;

- "[T]o prohibit in the Community the testing of cosmetic ingredients on animals and the marketing of cosmetics tested on animals or containing ingredients tested on animals as soon as alternative testing methods have been validated by the Commission, with due regard to validation within the Organization for Economic Co-operation and Development (OECD);

- " $[\mathrm{T}]$ o align the provisions of Directive 76/768/EEC with the rules of the World Trade Organization (WTO); and

- " $[\mathrm{T}] \mathrm{o}$ improve consumer information in relation to the use of cosmetic products."

The European Parliament and Council agreed to implement the marketing and testing bans in 2009, to give cosmetic companies time to develop non-animal tests.

The EU had previously rejected a June 2002 proposal to ban testing of cosmetic products on animals, fearing that it would

\section{Regulation Updates}

Bush Signs Legislation Creating the Department of Homeland Security On 25 November 2002, President Bush signed HR 5005 (ref. 4) creating the Department of Homeland Security (DHS). He also announced his nomination of former Pennsylvania governor Tom Ridge as secretary of the new department. The DHS will include the USDA's Plum Island Animal Disease Center (Plum Island, NY) and border patrol and inspection services. All other Animal and Plant Health Inspection Service (APHIS) departments will remain within USDA.

On 19 November 2002, Agriculture Secretary Ann M. Veneman released a statement in support of the passage of legislation to create a Department of Homeland Security. Veneman promised USDA cooperation with the Department of Homeland Security, adding, "USDA will be an active partner in helping ensure the safety of America's food and agriculture sector ${ }^{5}$."

\section{Florida Voters Amend State Constitution in Favor of Pregnant Sows}

On 5 November 2002, Floridians chose to amend their state constitution to prohibit commercial hog farmers from housing pregnant pigs in crates too small to turn around in ${ }^{6}$. "Gestation crates" are commonly used in high-volume pig farming to protect pregnant pigs from injuring each other. Only two of Florida's ten commercial hog farms currently use them ${ }^{7}$. As a result, this measure, while a significant development for the welfare of farm animals, will have only a limited effect on pig farming and the well-being of sows raised in Florida.

\section{DEA Reschedules Buprenorphine From Schedule V to Schedule III}

Buprenorphine, a semisynthetic opioid, has been classified as Schedule V drug since 1985. On 7 October 2002, the Drug Enforcement Agency (DEA) issued its final rule to reschedule buprenorphine from Schedule $\checkmark$ to Schedule III under the Controlled Substances ACT (CSA) ${ }^{8}$. This decision followed a rescheduling recommendation by the Department of Health and Human Services (DHHS) and a review by the DEA. As required by 21 USC 812 (b) for Schedule III control, the DEA determined that (1) buprenorphine has a potential for abuse less than the drugs or other substances in Schedules I and II; (2) buprenorphine has a currently accepted medical use in treatment in the US; and (3) abuse of buprenorphine may lead to moderate or low physical dependence or high psychological dependence. This change requires users of this drug - one of the most frequently used analgesics for laboratory animals - to update their DEA licenses appropriately.

disadvantage European exporters and violate world trade rules. If implemented, this new ban would affect the $\sim 8,000$ current cosmetic ingredients as well as any new ingredients used in the EU's \$44-billion-a-year cosmetic industry. Only three EU countries currently ban animal testing of cosmetic ingredients: Britain, Austria, and The Netherlands ${ }^{3}$.

\section{References}

1. Council Directive of 24 November 1986 on the approximation of laws, regulations and administrative provisions of the Member States regarding the protection of animals used for experimental and other scientific purposes (86/609/EEC).

http://europa.eu.int/comm/food/fs/aw/aw legislation/scientific/86-609-eec_en.pdf.

2. Parliament-Council Conciliation Committee. Agreement on the banning of animal testing for cosmetics. (7 November 2002). http://ue.eu.int/pressData/en/misc/73127.pdf.
3. Ames, Paul. EU may ban animal tests by 2009. Associated Press (7 November 2002).

4. HR 5005. Homeland Security Act of 2002. http://thomas.loc.gov.

5. Veneman, A.M. USDA Statement by Agriculture Secretary Ann M. Veneman regarding the creation of a Department of Homeland Security. USDA Release No. 0479.02. (19 November 2002). http://www.usda.gov/news/releases/ 2002/11/0479.htm.

6. Florida Department of State-Election Results. http://enight.dos.state.fl.us.

7. Reject 'pig' amendment 10. Palm Beach Post (FL) (25 October 2002). http://www. palmbeachcivic.org/election2002_news_ 021025_reject_pig_amendment $10 . \mathrm{html}$.

8. Drug Enforcement Administration, Department of Justice. Final Rule. Schedules of controlled substances: rescheduling of buprenorphine from schedule $\mathrm{V}$ to schedule III. Federal Register 67, 62354-62370 (7 October 2002). 